\title{
Gastrotrichs and tardigrades in a remnant of Atlantic Forest (Serra do Japi, SP, Brazil)
}

\author{
Emiliana Brotto Guidetti $^{1(\mathbb{D}}$, Ariane Campos $^{1}$, Alan Rodrigo Batistão ${ }^{1}{ }^{\circledR}$, Amanda Tognoli da Silva $^{1}$, \\ Carla Gabriela Bilatto ${ }^{1}$, Kelly Acosta Salgado ${ }^{1}$, Thiago Quintão Araújo ${ }^{1}$ \& André Rinaldo Senna Garraffoni ${ }^{1 *(1)}$ \\ ${ }^{1}$ Universidade Estadual de Campinas, Instituto de Biologia, Departamento de Biologia Animal, Laboratório de \\ Evolução de Organismos Meiofaunais, CEP 13083-970, Campinas, SP, Brasil. \\ *Corresponding author: e-mail: arsg@unicamp.br
}

GUIDETTI, E.B., CAMPOS, A., BATISTÃO, A.R., SILVA, A.T., BILATTO, C.G., SALGADO, K.A., ARAÚJO, T.Q., GARRAFFONI, A.R.S. Gastrotrichs and tardigrades in a remnant of Atlantic Forest (Serra do Japi, SP, Brazil). Neotropica 21(2): e20201165. https://doi.org/ 10.1590/1676-0611-BN-2020-1165

\begin{abstract}
Serra do Japi, located in the southeast of São Paulo State, is considered a priority area for conservation, as it houses original Atlantic Forest cover remains. Despite the significant number of studies about vertebrates and invertebrates that were carried out in this region, the meiofauna biodiversity is completely unknown. Thus, the present study aimed to investigate for the first time freshwater Gastrotricha and limnoterrestrial Tardigrada in Serra do Japi Biological Reserve. Samples of sediments, periphyton and floating vegetation in reservoirs and natural lagoons, and mosses growing on native and non-native tree trunks were collected in May 2019. At least five gastrotrichs morphotypes were identified and three of them were formally described: Chaetonotus acanthocephalus, C. dadayi (first record in Brazil), and Heterolepidoderma mariae (first record outside the type locality). In regards to tardigrades, twelve morphotypes were identified and four of them were formally described: Pseudechiniscus juanitae, Minibiotus cf. acontistus, Echiniscus dreyfusi and Itaquascon umbellinae (last two species reported for the first time outside the type locality). This study reinforces that meiofaunal diversity and distribution have been underestimated, even in one of the five largest hotspots in the world.
\end{abstract}

Keywords: Checklist, meiofauna, floating vegetation, moss.

\section{Gastrótricos e tardígrados em um remanescente de Mata Atlântica (Serra do Japi, SP, Brasil)}

\begin{abstract}
Resumo: A Serra do Japi, localizada no sudeste do Estado de São Paulo, é considerada uma área prioritária para conservação, por abrigar vestígios de cobertura original de Mata Atlântica. Apesar do número significativo de estudos sobre vertebrados e invertebrados realizados nesta região, a biodiversidade de grupos meiofaunais é completamente desconhecida. Assim, o presente estudo teve como objetivo investigar pela primeira vez Gastrotricha de água doce e Tardigrada limnoterrestre na Reserva Biológica da Serra do Japi. As amostras de sedimentos, perifíton e vegetação flutuante em reservatórios e lagoas naturais, e musgos presentes em troncos de árvores nativas e não nativas foram coletadas em maio de 2019. Foram encontrados cinco morfotipos de gastrótricos, sendo que apenas três deles já foram formalmente descritos: Chaetonotus acanthocephalus, C. dadayi (primeiro registro no Brasil) e Heterolepidoderma mariae (primeiro registro fora da localidade-tipo). Em relação aos tardígrados, foram identificados doze morfotipos, sendo que quatro deles já formalmente descritos: Pseudechiniscus juanitae, Minibiotus cf. acontistus, Echiniscus dreyfusi e Itaquascon umbellinae (as duas últimas espécies relatadas pela primeira vez fora da localidade-tipo). Este trabalho reforça que a diversidade e distribuição da meiofauna têm sido subestimadas, mesmo em um dos cinco maiores hotspots do mundo.
\end{abstract}

Palavras-chave: Lista de espécies, meiofauna, vegetação flutuante, musgo. 


\section{Introduction}

Meiofauna can be defined as an assembly of freshwater and marine organisms that pass through a coarse sieve of $500 \mu \mathrm{m}$ and are retained by a finer sieve of $44 \mu \mathrm{m}$ and do not have close phylogenetic relationships among them (Giere 2009). These animals can be classified as permanent, having an entire life as small organisms, or temporary, having one or more stages of the life cycle with 'meiofaunal' body size (Higgins \& Thiel 1988). Beside in the water bodies of rivers and lakes, freshwater meiofauna can be found in distinct environments, such as rooted vegetation, macroalgae fronds, mosses, and some animal structures like worm tubes (Higgins \& Thiel 1988, Boeckner et al. 2009, Giere 2009).

Among the 34 phyla of Metazoa, there are at least 23 that have meiofaunal organisms, such as Gastrotricha and Tardigrada (Giere 2009, Cerca et al. 2018). Gastrotricha are microinvertebrates living in marine (e.g. among sand grains and algae) and freshwater (e.g. aquatic plants and psammon) habitats around the world (Balsamo et al. 2014, 2020, Kieneke \& Schmidt-Rhaesa 2015). The taxon is divided into two orders: Macrodasyida, with a worm-like body consisting of 380 species, all marine except for four species (Garraffoni et al. 2019a, Balsamo et al. 2020); Chaetonotidae, with a tenpin-shaped body consisting of 480 species, two-thirds of which reported in freshwater (Balsamo et al. 2008, 2014, 2020). Tardigrada, commonly known as water bears, living in marine (e.g. sand grains, rock shore, barnacles), freshwater (e.g. aquatic plants and psammon), and limnoterrestrial (e.g. bryophytes, cushion-forming plants, lichens, algae, soils) habitats (Nelson et al. 2015). The taxon comprises more than 1300 species divided into two valid classes: Heterotardigrada (majority marine); and Eutardigrada (freshwater and limnoterrestrial). The existence of a third class, Apotardigrada (freshwater and limnoterrestrial) has been previously discussed (Guil et al. 2019, Morek et al. 2020).

Due to the meiofaunal body size and challenging identification process, the knowledge about gastrotrichs and tardigrades' diversity in the world is underestimated (Vicente 2010, Appeltans et al. 2012; Balsamo et al. 2014, 2015, 2020, Fonseca et al. 2018, Garraffoni et al. 2019b). Notwithstanding, a few studies have aimed to reveal the richness and distributional patterns of these two freshwater and limnoterrestrial meiofauna taxa in Brazil (de Barros R 1939a, b, 1942a, b, 1943, Kisielewski 1991, Assunção 1999, Pilato et al. 2002b, Garraffoni et al. 2010, 2017a, b, 2019a, Garraffoni \& Melchior
2015, Araújo et al. 2013, Rocha et al. 2016, Garraffoni 2017, de Barros RC 2020). This study aims to contribute to this knowledge by presenting the first records of gastrotrichs and tardigrades at the Biological Reserve of Fundação Serra do Japi, an extensive area of Atlantic Forest located in São Paulo State. In addition, this manuscript provides taxonomic notes of the morphotypes and formally described species found at the Reserve.

\section{Material and Methods}

\section{Study site}

Serra do Japi is located in the southeast of São Paulo, bordering four cities (Jundiaí, Pirapora do Bom Jesus, Cajamar and Cabreúva), between the geographical coordinates $23^{\circ} 14^{\prime} 0^{\prime \prime} \mathrm{S}$ and $46^{\circ} 58^{\prime} 0^{\prime \prime} \mathrm{W}$. The elevation has an area of approximately 35,000 hectares and a native vegetation cover of semi-deciduous mesophyllous forests, semi-deciduous forests of altitude, and sparse rocky enclaves (Morellato 1992) and fragments of reforestation with pine and Eucalyptus sp., pastures, and small portions of agricultural crops. The altitudinal ranges vary between 700 and 1,000 meters (Pinto et al. 1972). In the coldest month, July, the average temperatures range between $11.8^{\circ} \mathrm{C}$ and $15.3^{\circ} \mathrm{C}$, and in the warmest month, January, between $18.4^{\circ} \mathrm{C}$ and $22.2^{\circ} \mathrm{C}$ depending on the altitude (Morellato 1992). The rainfall cycle is variable, increasing in the months of December-January, with values greater than $250 \mathrm{~mm}$ per month, and decreasing in the winter, with values lower than $41 \mathrm{~mm}$ and $71 \mathrm{~mm}$ per month, depending on the location (Morellato 1992).

\section{Collecting procedures and Data analysis}

Samples were collected from May $18^{\text {th }}$ to $19^{\text {th }}, 2019$. Gastrotricha specimens were sampled by collecting specimens of the floating vegetation belonging to Salvinia sp. from a small artificial reservoir $\left(23^{\circ} 14^{\prime} 42.8^{\prime \prime} \mathrm{S}\right.$, $\left.46^{\circ} 56^{\prime} 12.4^{\prime \prime} \mathrm{W}\right)$ and natural lagoon (2314'47.3”S, 46 $\left.56^{\circ} 12.4^{\prime \prime} \mathrm{W}\right)$ and stored in plastic buckets. Tardigrada specimens were sampled by collecting mosses belonging to family Pottiaceae on native (2314'21.9's, $46^{\circ} 56^{\prime} 07.6^{\prime} \mathrm{W}$ ) and from Sematophyllum galipense (Müll.Hal.) Mitt. on

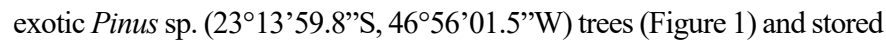
in paper bags. Freshwater and limnoterrestrial samples were brought back to the University of Campinas for further analysis.

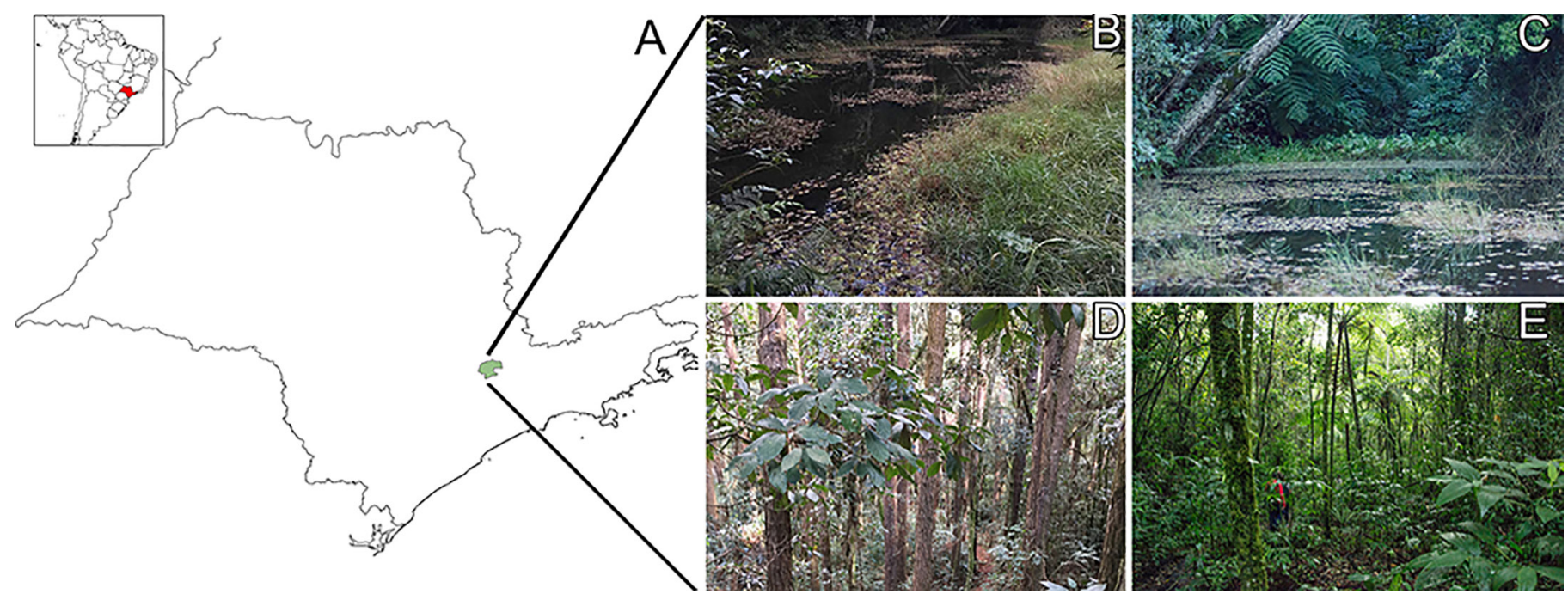

Figure 1. Map of collection stations. A: Serra do Japi Biological Reserve, B: floating vegetation from an artificial small reservoir, C: natural lagoon, D: exotic Pinus sp. tree trunks, E: mosses from the Atlantic Forest. 
Water with sediment was sieved (42 $\mu \mathrm{m}$ mesh) and specimens were encountered by sorting small amounts of sediment poured into Petri dishes under a Zeiss Stemi 2000 stereomicroscope. Mosses were placed in a beaker filled with $\mathrm{ddH}_{2} \mathrm{O}$, and after 20 minutes the water was transferred to Petri dishes and the specimens were scanned under a Zeiss Stemi 2000 stereomicroscope.

Alive specimens were isolated with micropipettes into a glass embryo dish. The gastrotrichs and tardigrades were anesthetized with $2 \% \mathrm{MgCl}_{2}$ and warm water $\left(70^{\circ} \mathrm{C}\right)$, respectively. Subsequently, gastrotrichs were isolated and mounted on glass slides and tardigrades were stored in $70 \%$ ethyl alcohol and permanent slides were made using Fluoromount Aqueous Mounting medium. All specimens were documented under a Zeiss Axio Imager M2 light microscope equipped with Differential Interference Contrast optics (DIC) connected to a camera. Photomicrographs were taken using the software ZEN - blue edition. The most representative structures of tardigrades identified up to the specific level were measured. Methods and terminology used to measure the specimens of Echiniscus dreyfusi followed Bartylak et al. (2019); Pseudechiniscus juanitae followed Roszkowska et al. (2020); Itaquascon umbellinae followed Pilato et al. (2002a), Minibiotus cf. acontistus followed Kaczmarek \& Michalczyk 2017. Morphometric data was handled using "Echiniscoidea" and "Parachela" templates available from the Tardigrada Register (Michalczyk \& Kaczmarek 2013).

Photos of Gastrotricha (due to the fragility of their bodies, they were destroyed during the microscopic examination and are no longer available Balsamo et al. 2014, 2020, Garraffoni et al. 2019b) and photos and permanent slides of Tardigrada specimens are available at the Zoological Museum "Adão José Cardoso" (ZUEC), at the University of Campinas, Brazil.

\section{Results}

At least five morphospecies ( 38 specimens) of Gastrotricha belonging to two genera of Chaetonotidae were present. Among these five morphospecies, three were attributed to described species (Chaetonotus dadayi Schwank, 1990, Chaetonotus acanthocephalus Valkanov, 1937 and Heterolepidoderma mariae Garraffoni \& Melchior, 2015). A total of 12 morphospecies (32 specimens) belonging to two classes of Tardigrada were present. Among these 12 morphospecies, eight were identified at the genus level and four were attributed to described species (Itaquascon umbellinae de Barros R, 1939a, Pseudechiniscus juanitae de Barros R, 1939b, Minibiotus cf. acontistus de Barros R, 1942b and Echiniscus dreyfusi de Barros R, 1942a). The remaining morphospecies could not be described to species level due to problems in the fixation process (see Discussion).

\section{Phylum Gastrotricha}

Order Chaetonotida Remane, 1925 [Rao \& Clausen, 1970]

Suborder Paucitubulatina d'Hondt, 1971

Family Chaetonotidae Gosse, 1864 [Garraffoni, Araújo, Lourenço, Guidi \& Balsamo, 2017b]

Subfamily Chaetonotinae Kisielewski, 1991

Genus Chaetonotus Ehrenberg, 1830

Chaetonotus (Primochaetus) acanthocephalus Valkanov, 1937 Figure 2 (A-C)

Examined material: One specimen (ZUEC PIC 390).
Remarks: C. acanthocephalus is easily recognized by the presence of five dorsal cephalic scales with long spines, two plates at the side of the hypostomium, and the arrangement of dorsal and lateral spines (e.g. two pairs at the neck, transversal row at the mid-dorsal surface). This species was previously reported in Poland, Germany, Romania, Bulgari (Valkanov 1937, Kisielewski 1981, Schwank 1990) and Brazil (Kisielewski 1991, Garraffoni et al. 2010, Araújo et al. 2013).

\section{Chaetonotus (Chaetonotus) dadayi Schwank, 1990}

Figure 2 (D-F)

Examined material: Fourteen specimens (ZUEC PIC 377-389).

Remarks: Von Daday (1905) identified specimens found on the border between Paraguay and Brazil, in Estia Postillon, as Chaetonotus similis Zelinka, 1889. Later, Schwank (1990) recognized that the specimens analyzed by Von Daday (1905) had a pair of spines that protruded beyond the adhesive tubes. This feature is not observed in Chaetonotus similis and Schwank (1990) described a new species, $C$. dadayi, to accommodate the Paraguayans organisms. Several years later, d'Hondt (2006) found C. dadayi in French Guiana and presented the first photographic record of a specimen of this species. The Brazilian specimens are morphologically close to the previous descriptions due to the presence of spined scales of the posterior dorsal region smaller than the trunk ones, lateral spined scales of the furca base longer than adhesive tubes; two pairs of long, thick, and simple spines on the dorsal
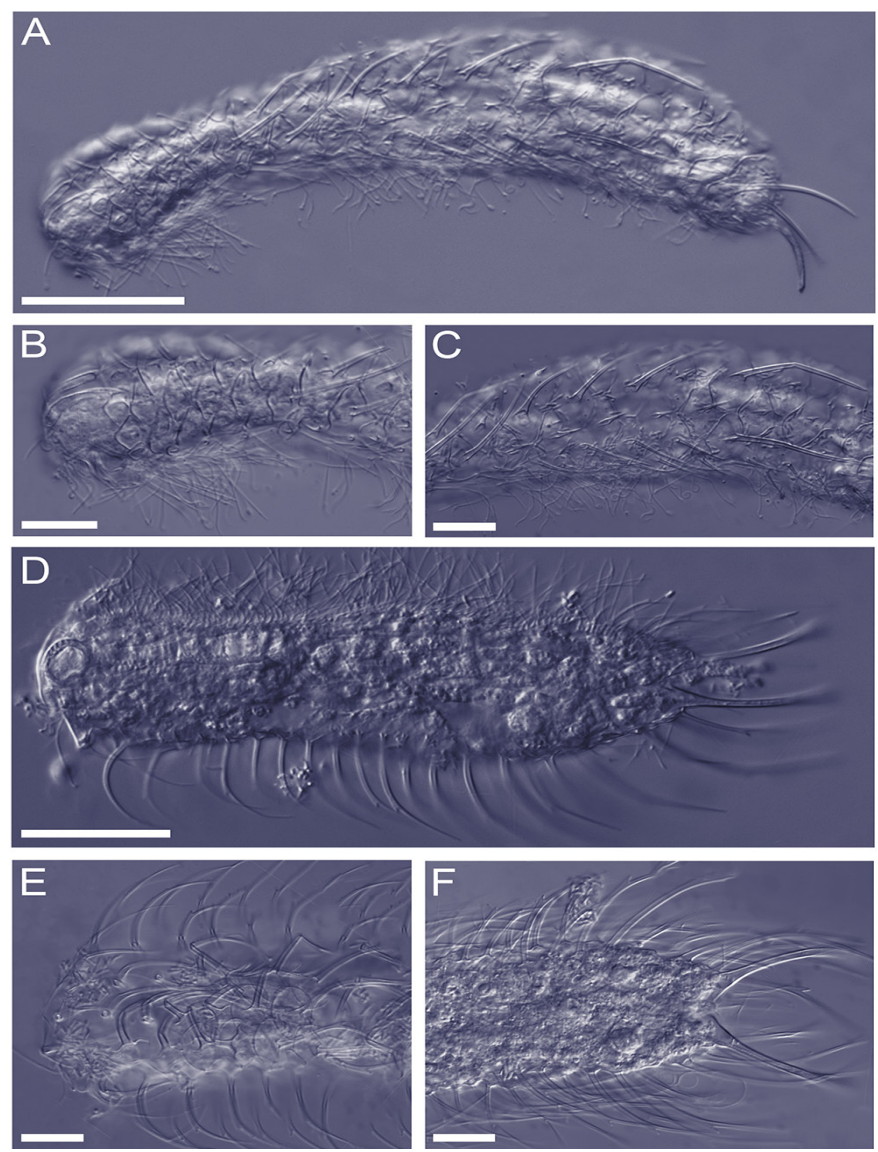

Figure 2. DIC photomicrograph of Gastrotricha. A-C: Lateral view of Chaetonotus (Primochaetus) acanthocephalus, D, F: Ventral view of Chaetonotus (Chaetonotus) dadayi, E: Dorsal view of Chaetonotus (Chaetonotus) dadayi. Scale bars: $50 \mu \mathrm{m}$. 
region and two pairs of scales with long, thin and simple spines in the ventral region. This is the first report from Brazil.

\section{Chaetonotus sp. 1}

Figure 3 (A-C)

Examined material: Four specimens.

Remarks: Mouth terminal; pentalobate head. Trilobate spined scales on dorsal and ventrolateral regions; spines increasing in length along the body; set of nine long and thick spines arranged as 3-3-3 on the middle dorsal region. Ventral interciliary portion covered by small spined scales.

\section{Chaetonotus sp. 2}

Examined material: Six specimens.

Remarks: Mouth subterminal; small cephalic hypostomium. Rounded spined double-edge scales on dorsal and ventrolateral regions; dorsal spines increasing in length from head to middle trunk and decreasing until the posterior end; pair of long spines observed at the furcal base. Ventral interciliary portion covered by small rounded spined scales.

Genus Heterolepidoderma Remane, 1927

Heterolepidoderma mariae Garraffoni \& Melchior, 2015 Figure 3 (D)
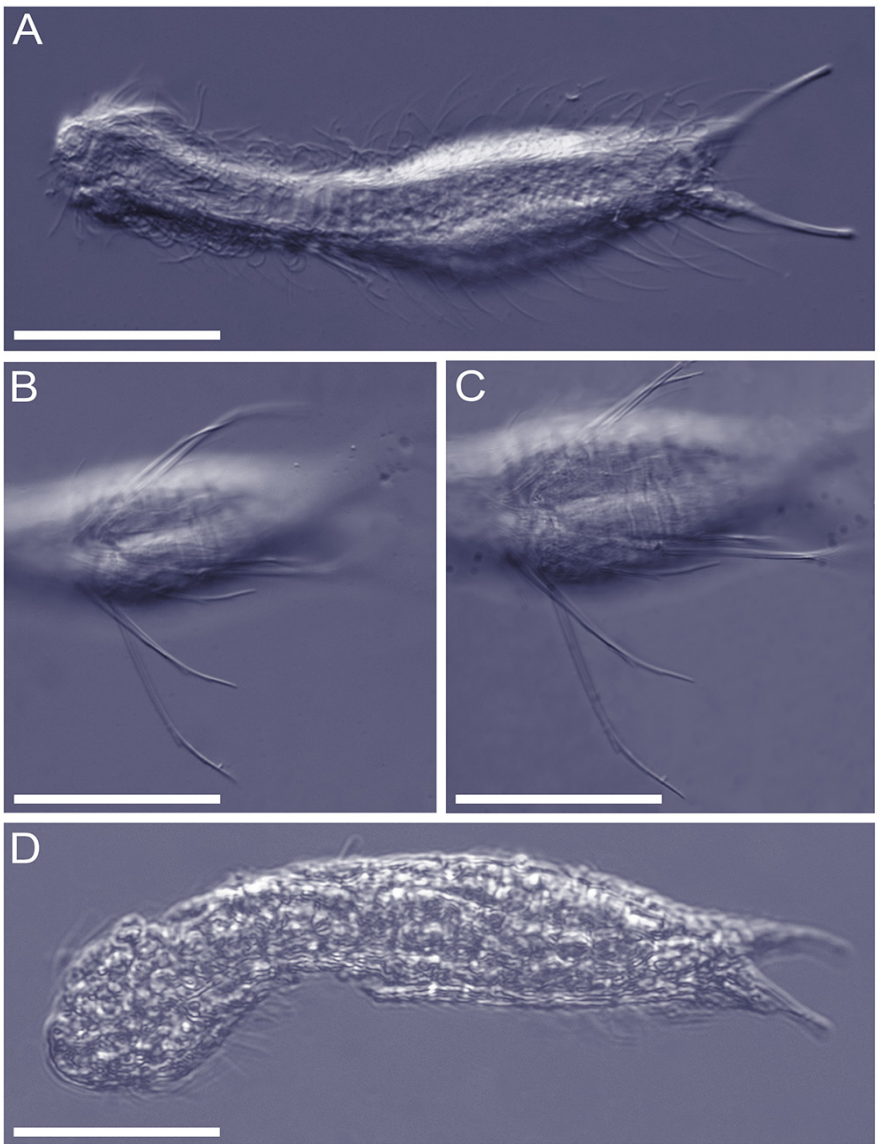

Figure 3. DIC photomicrograph of Gastrotricha. A: Ventral view of Chaetonotus sp. 1, B-C: Dorsal view of Chaetonotus sp. 1, D: Ventral view of Heterolepidoderma mariae. Scale bars: $50 \mu \mathrm{m}$.
Examined material: Six specimens (ZUEC PIC 391-396).

Remarks: Heterolepidoderma mariae can be easily recognized by specific cuticular ornamentation of the dorsal body surface, keeled scales with three different shapes. It is the first report outside the type locality, Paulínia - São Paulo State, Brazil (Garraffoni \& Melchior 2015).

\author{
Phylum Tardigrada \\ Class Heterotardigrada Marcus, 1927 \\ Order Echiniscoidea Richters, 1926 \\ Family Echiniscidae Thulin, 1928
}

Genus Echiniscus Schultze, 1840

\section{Echiniscus dreyfusi de Barros R, 1942}

Figure 4 (A), Table 1

Examined material: One specimen, unidentified sex, (ZUEC PIC 402).

Remarks: The specimen found in Serra do Japi has four features not mentioned in the original description of Echiniscus dreyfusi: thick granulation on the dorsal side of the legs; spine present on the first pair of legs; spurs on claws of the third and fourth pairs of legs; the dorsal pair of spines has a striated texture. This species was previously reported in New Guinea (Iharos 1963), Argentina (Claps \& Rossi 1988), Japan (Utsugi 1988), and Brazil (de Barros R 1942a). In Brazil, it is the first report outside the type locality, São Vicente City - São Paulo State.

\section{Echiniscus sp.}

Figure 4 (B)

Examined material: One specimen, unidentified sex.

Remarks: Body orange and plump. Dorsal plates with large pores irregularly distributed; spinulosus type. Trunk appendages in the form of spines; spines $\mathrm{D}^{\mathrm{d}}$ and $\mathrm{E}$ more robust and rough. There is a small denticle on each $\mathrm{D}^{\mathrm{d}}$ spine. Small spine on the first leg pair. Papilla and dentate collar present on the fourth leg pair.

Genus Pseudechiniscus Thulin, 1911

\section{Pseudechiniscus juanitae de Barros R, 1939}

Figure 4 (C), Table 2

Examined material: Three specimens, unidentified sex, (ZUEC PIC 399-401).

Remarks: Body orange. Round black eyes present in two specimens. Cirrus internus, externus and A present. Clava visible in one specimen. Pseudosegmental plate present. Very visible cuticular granulation on the dorsal plates and legs. Papilla on the fourth pair of legs visible in one specimen. Dentate collar absent. Spurs on claws IV present. Spurs on claws I visible in one specimen. This species was previously reported in Austria (Mihelcic 1962, Maucci 1974), Italy (Ramazzotti \& Maucci 1983), Galápagos Islands (Schuster \& Grigarick 1966), China (Wang 2009), and Brazil (de Barros R 1939b, 1942a, du Bois-Reymond Marcus 1944).

Class Eutardigrada Richters, 1926

Order Parachaela Schuster, Nelson, Grigarick \& Christenberry, 1980 
Family Macrobiotidae Thulin, 1928

Genus Paramacrobiotus Guidetti, Schill, Bertolani, Dandekar \& Wolf, 2009

\section{Paramacrobiotus sp. 1}

Figure 4 (D)

Examined material: Three specimens, unidentified sex.

Remarks: Eyes present in only one specimen. Cuticle smooth. Oral cavity armature (OCA) composed of three bands of teeth. Pharyngeal apophysis present and very visible. Three macroplacoids present and separated by the same distance from each other; the second macroplacoid is the smaller; the third macroplacoid has a small constriction; very small triangular microplacoids present. Claws of the hufelandi type.

\section{Paramacrobiotus sp. 2}

Figure 4 (E)

Examined material: Four specimens, unidentified sex.

Remarks: Eyes present in two specimens. Cuticle smooth except for very visible granulation present on all legs. Oral cavity armature composed of three bands of teeth. Pharyngeal apophysis present; three macroplacoids present; the second is the smaller and the third is positioned more distant from the others; the third macroplacoid has a small constriction; microplacoids absent. Claws of the hufelandi type. Dentate lunules under claws IV.

\section{Paramacrobiotus sp. 3}

Examined material: Two specimens, unidentified sex.

Remarks: Eyes absent. Cuticle smooth except for very visible granulation present on all legs. Oral cavity armature (OCA) composed of three bands of teeth. Pharyngeal apophysis present. Three macroplacoids present; the second is the smaller and the third is positioned more distant from the others; the third macroplacoid has a small constriction; very
Table 1. Measurements [in $\mu \mathrm{m}$ ] and $s c$ values of selected morphological structures of Echiniscus dreyfusi de Barros R, 1942. The sc is the percentage of scapular plate length (Fontoura et al. 2008).

\begin{tabular}{|c|c|c|}
\hline CHARACTER & $\mu \mathrm{m}$ & $s c$ \\
\hline Body length & 279 & 575 \\
\hline Scapular plate length & 48.5 & - \\
\hline \multicolumn{3}{|l|}{ Head appendages lengths } \\
\hline Cirrus internus & 20.5 & 41.2 \\
\hline Cephalic papilla & 8.3 & 17.1 \\
\hline Cirrus externus & 20.0 & 41.2 \\
\hline Clava & 8.5 & 17.5 \\
\hline Cirrus A & 40.8 & 84.1 \\
\hline Cirrus A/Body length ratio & $15 \%$ & - \\
\hline Cirrus int/ext length ratio & $100 \%$ & - \\
\hline \multicolumn{3}{|l|}{ Body appendages lengths } \\
\hline Cirrus B & 20.5 & 42.3 \\
\hline Cirrus C & 34.5 & 71.1 \\
\hline Cirrus D & 32.0 & 66.0 \\
\hline Cirrus Dd & 30.0 & 61.9 \\
\hline Cirrus E & 37.2 & 76.6 \\
\hline Spine on leg I length & 5.4 & 11.1 \\
\hline \multicolumn{3}{|l|}{ Claw 1 heights } \\
\hline Branch & 13.2 & 27.2 \\
\hline \multicolumn{3}{|l|}{ Claw 2 heights } \\
\hline Branch & 12.5 & 25.8 \\
\hline \multicolumn{3}{|l|}{ Claw 3 heights } \\
\hline Branch & 11.7 & 24.1 \\
\hline Spur & 4.1 & 8.5 \\
\hline Spur/branch height ratio & $35 \%$ & - \\
\hline \multicolumn{3}{|l|}{ Claw 4 heights } \\
\hline Branch & 16.3 & 33.6 \\
\hline Spur & 4.3 & 8.9 \\
\hline Spur/branch height ratio & $26 \%$ & - \\
\hline
\end{tabular}
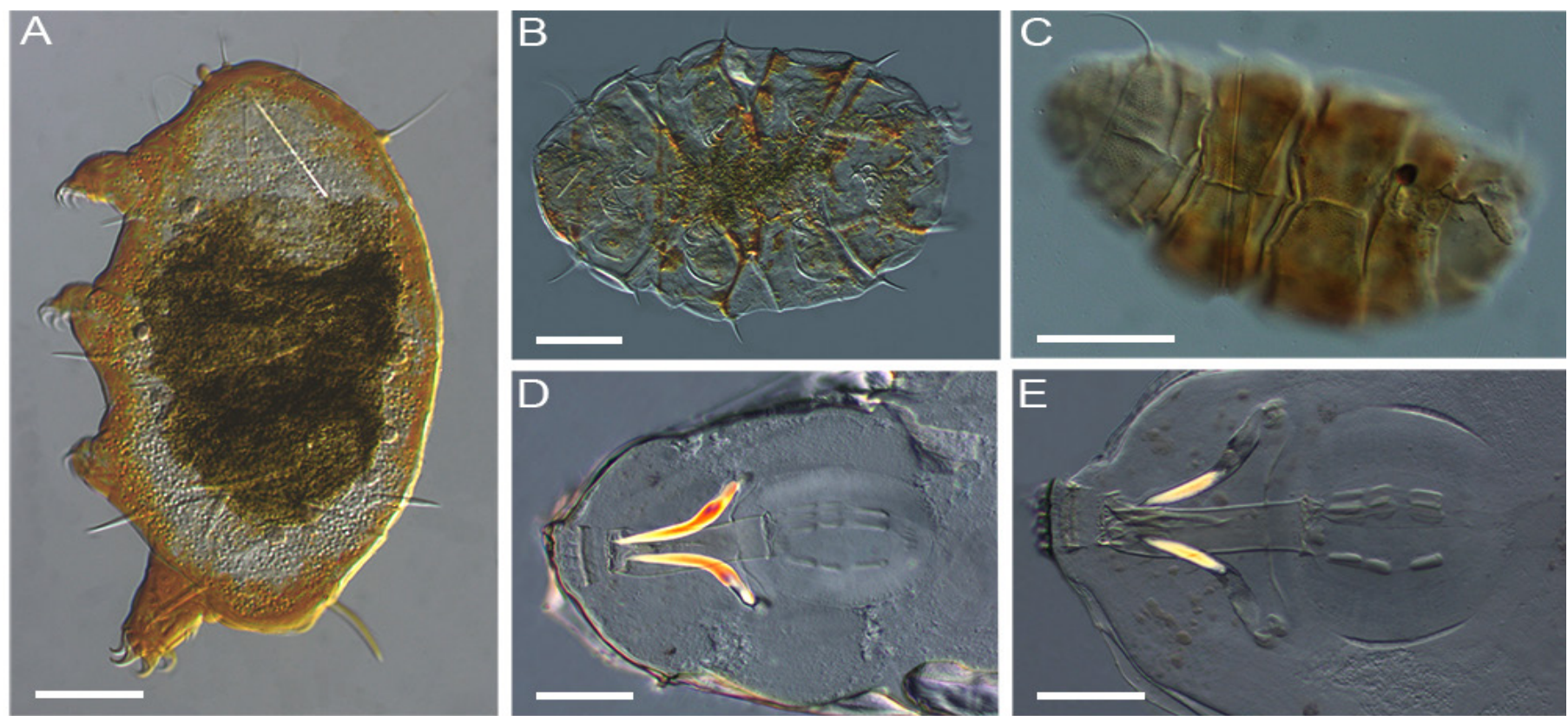

Figure 4. DIC photomicrograph of Tardigrada. A: Dorsal view of Echiniscus dreyfusi, B: Ventral view of Echiniscus sp. C: Dorsal view of Pseudechiniscus juanitae, D: Buccal apparatus of Paramacrobiotus sp. 1, E: Buccal apparatus of Paramacrobiotus sp. 2. Scale bars: $50 \mu \mathrm{m}$. 
Guidetti, E.B. et al.

Table 2. Measurements [in $\mu \mathrm{m}$ ] and $s c$ values of selected morphological structures of Pseudechiniscus juanitae de Barros R, 1939b. The $s c$ is the percentage of scapular plate length (Fontoura et al. 2008).

\begin{tabular}{|c|c|c|c|c|c|c|}
\hline CHARACTER & $\mu \mathbf{m}$ & $s c$ & $\mu \mathbf{m}$ & $s c$ & $\mu \mathrm{m}$ & $s c$ \\
\hline Body length & 263 & 793 & 181 & 755 & 301 & 564 \\
\hline Scapular plate length & 33.2 & - & 24.1 & - & 53.4 & - \\
\hline Cirrus internus & 19.3 & 58.0 & & & 13.4 & 25.1 \\
\hline \multicolumn{7}{|l|}{ Cephalic papilla } \\
\hline Cirrus A & & & 32.3 & 134.2 & 40.1 & 75.0 \\
\hline Cirrus A/Body length ratio & & - & $18 \%$ & - & $13 \%$ & - \\
\hline Cirrus int/ext length ratio & $51 \%$ & - & & - & $46 \%$ & - \\
\hline Papilla on leg IV length & & & 5.4 & 22.6 & & \\
\hline Spur/branch height ratio & & - & & - & $27 \%$ & - \\
\hline \multicolumn{7}{|l|}{ Claw 2 heights } \\
\hline Branch & & & 8.4 & 34.7 & & \\
\hline \multicolumn{7}{|l|}{ Spur } \\
\hline Spur/branch height ratio & & - & & - & & - \\
\hline \multicolumn{7}{|l|}{ Claw 4 heights } \\
\hline Branch & 11.2 & 33.7 & 9.2 & 38.2 & & \\
\hline Spur & 3.0 & 9.0 & 3.7 & 15.5 & & \\
\hline Spur/branch height ratio & $27 \%$ & - & $41 \%$ & - & & - \\
\hline
\end{tabular}

small triangular microplacoids present. Claws of the hufelandi type. Dentate lunules under claws IV.

Genus Macrobiotus Schultze, 1834

\section{Macrobiotus sp. 1}

Figure 5 (A)

Examined material: Four specimens, unidentified sex.

Remarks: Eyes absent. Dorsal cuticle with very visible ornamentation forming polygons like scales of reptiles; thin granulation present on all legs. Bucco-pharyngeal apparatus of the Macrobiotus type. Pharyngeal apophysis present; three short and wide macroplacoids present; large microplacoids present. Claws of the hufelandi type. Cuticular bars on legs I-III.

\section{Macrobiotus sp. 2}

Examined material: Two specimens, unidentified sex.

Remarks: Eyes present. Cuticle smooth. Pharyngeal apophysis presents; three slender macroplacoids present, the third being positioned more distant from the others. Claws of the hufelandi type.

Genus Minibiotus Schuster, 1980

Minibiotus cf. acontistus de Barros R, 1942b
Examined material: One specimen, unidentified sex (ZUEC PIC 398).

Remarks: Eyes absent. Cuticle smooth. Buccal tube long and narrow. Three macroplacoids present; microplacoids absent. Claws of the hufelandi type (claws Y-shaped; symmetrically arranged with respect to the median plane of the leg; without basal spurs).

\section{Minibiotus sp.}

Figure 5 (B)

Examined material: Eight specimens, unidentified sex.

Remarks: Eyes present only in two specimens. Cuticle smooth. Buccal tube long and narrow. Large pharyngeal apophyses present. Three macroplacoids present; microplacoids present and very small. Claws of the hufelandi type.

Family Hypsibiidae Pilato, 1969

Subfamily Itaquasconinae Rudescu, 1964

Genus Itaquascon de Barros R, 1939a

Itaquascon umbellinae de Barros R, 1939a

Figure 5 (C), Table 4

Examined material: One specimen, unidentified sex (ZUEC PIC 397).

Table 3 
Table 3. Measurements [in $\mu \mathrm{m}$ ] and $p t$ values of selected morphological structures of Minibiotus cf. acontistus de Barros R, 1942b. The pt index is the ratio of the length of a given structure to the length of the buccal tube expressed as a percentage (Pilato 1981).

\begin{tabular}{|c|c|c|}
\hline CHARACTER & $\mu \mathrm{m}$ & $p t$ \\
\hline Body length & 180 & 662 \\
\hline Buccal tube length & 27.2 & - \\
\hline Pharyngeal tube length & 6.8 & 25.0 \\
\hline Buccopharyngeal tube length & 34.0 & 125.0 \\
\hline Buccal/pharyngeal tube length ratio & $400 \%$ & - \\
\hline Stylet support insertion point & 25.0 & 91.9 \\
\hline Buccal tube external width & 2.3 & 8.5 \\
\hline Buccal tube internal width & 1.3 & 4.6 \\
\hline \multicolumn{3}{|l|}{ Placoid lengths } \\
\hline Macroplacoid 1 & 2.0 & 7.2 \\
\hline Macroplacoid 2 & 2.8 & 10.1 \\
\hline Macroplacoid 3 & 2.3 & 8.4 \\
\hline Macroplacoid row & 12.2 & 44.9 \\
\hline \multicolumn{3}{|l|}{ Claw 1 heights } \\
\hline External primary branch & 4.9 & 18.0 \\
\hline External secondary branch & 4.7 & 17.3 \\
\hline Internal primary branch & 5.4 & 19.9 \\
\hline Internal secondary branch & 4.8 & 17.6 \\
\hline \multicolumn{3}{|l|}{ Claw 2 heights } \\
\hline External primary branch & 5.8 & 21.3 \\
\hline External secondary branch & 5.1 & 18.8 \\
\hline Internal primary branch & 6.2 & 22.8 \\
\hline Internal secondary branch & 6.0 & 22.1 \\
\hline \multicolumn{3}{|l|}{ Claw 3 heights } \\
\hline External primary branch & 6.7 & 24.6 \\
\hline External secondary branch & 5.0 & 18.4 \\
\hline Internal primary branch & 5.3 & 19.5 \\
\hline Internal secondary branch & 4.3 & 15.8 \\
\hline \multicolumn{3}{|l|}{ Claw 4 heights } \\
\hline Anterior primary branch & 6.8 & 24.8 \\
\hline Anterior secondary branch & 5.6 & 20.4 \\
\hline Posterior primary branch & 8.0 & 29.4 \\
\hline Posterior secondary branch & 7.2 & 26.5 \\
\hline
\end{tabular}

Remarks: Eyes absent. Cuticle smooth. Buccal tube long and narrow; pharyngeal bulb oval without placoids. Claws of the Hypsibius type (the secondary branch and the basal section form a continuous curve; claws of the same leg are different in size and shape). This species was described from Itaquaquecetuba, São Paulo State, Brazil (de Barros R 1939a), and reported in Argentina (Maucci 1988). In Brazil, this is the first report outside the type locality.

Genus Adropion Pilato, 1987

\section{Adropion sp.}

Figure 5 (D)

Examined material: One specimen, unidentified sex.
Remarks: Eyes absent. Cuticle smooth. Cuticular thickening between the buccal tube (rigid) and the pharyngeal tube (flexible) absent. Pharyngeal apophyses are small. Three macroplacoids present; microplacoids present. Claws of the Hypsibius type.

\section{Discussion}

Meiofauna organisms are represented in $2 / 3$ of all known metazoan taxa (Giere 2009, Cerca et al. 2018) and it is impossible to apply a unique methodological protocol to perform fixation and preparation for all meiofaunal taxa (Fonseca et al. 2018). As a consequence, a large amount of these tiny animals, that have small, fragile bodies, remains poorly studied by researchers since the process of sorting and identification is intensive and time sensitive (Appeltans et al. 2012, Fonseca et al. 2018, Garraffoni et al. 2019b, Balsamo et al. 2020).

The examination of living microscopic organisms requires patience from the taxonomists, especially those that are beginners in meiofaunal identification. The small size and transparency of the body of meiofaunal individuals make them difficult to be discovered among sediments and for subsequent steps such as collecting them by pipette and isolating them for further studying (Giere 2009, Balsamo et al. 2014, 2020, Nelson et al. 2015). Furthermore, gastrotrichs must be studied alive and are frequently destroyed or even lost during the process of preparation for observations under light microscopy (Balsamo et al. 2014, 2020, Garraffoni et al. 2019b).

If the specimens are not properly fixed, they can easily vanish or not stay in a suitable position for future observations of the morphological features (Nelson et al. 2015, Fonseca et al. 2018, Garraffoni et al. 2019b, Balsamo et al. 2014, 2020). In these cases, due to losses of important morphological information, the accuracy of the species identification decreases, and misidentifications are inevitable (Schill 2018). Even in tardigrades that have an exocuticle that remains preserved after the fixation process, morphological information of taxonomic importance can be lost (Morek et al. 2016).

This study is a direct result of undergraduate lectures that aimed to teach not only meiofaunal diversity but also how to collect, sort, and identify these tiny animals, using gastrotrichs and tardigrades as study models. Thus, all the problems described above were considered and largely overcome by the students during the lectures. As a result, we found at least five morphospecies of Gastrotricha and 12 of Tardigrada, but within these 17 morphospecies, only seven of them $(41,2 \%)$ were identified at a specific level. It is important to highlight that we could not find more morphospecies of Gastrotricha because many specimens were poorly fixed or deteriorated, preventing proper identification beyond the genus level.

Regarding the gastrotrichs, two of the three identified species and all unidentified morphotypes belong to the most specious genus in the taxon, Chaetonotus Ehrenberg, 1830 with more than 250 species formally described (Balsamo et al. 2020). The species Chaetonotus dadayi was found in Brazil for the first time and these samples will be important to provide material for a near future redescription of this species providing detailed morphological and ecological data.

The morphotype Chaetonotus sp. 1 has a remarkable feature of nine long spines arranged in three subsequent groups of three spines in the middle of the trunk on the dorsal surface. These conspicuous spines in the middle of the trunk are found in other representatives of this taxon and can be arranged in a "belt", in a subsequent transverse row, or inserted in large nearby scales forming a grouping (Araújo et al. 

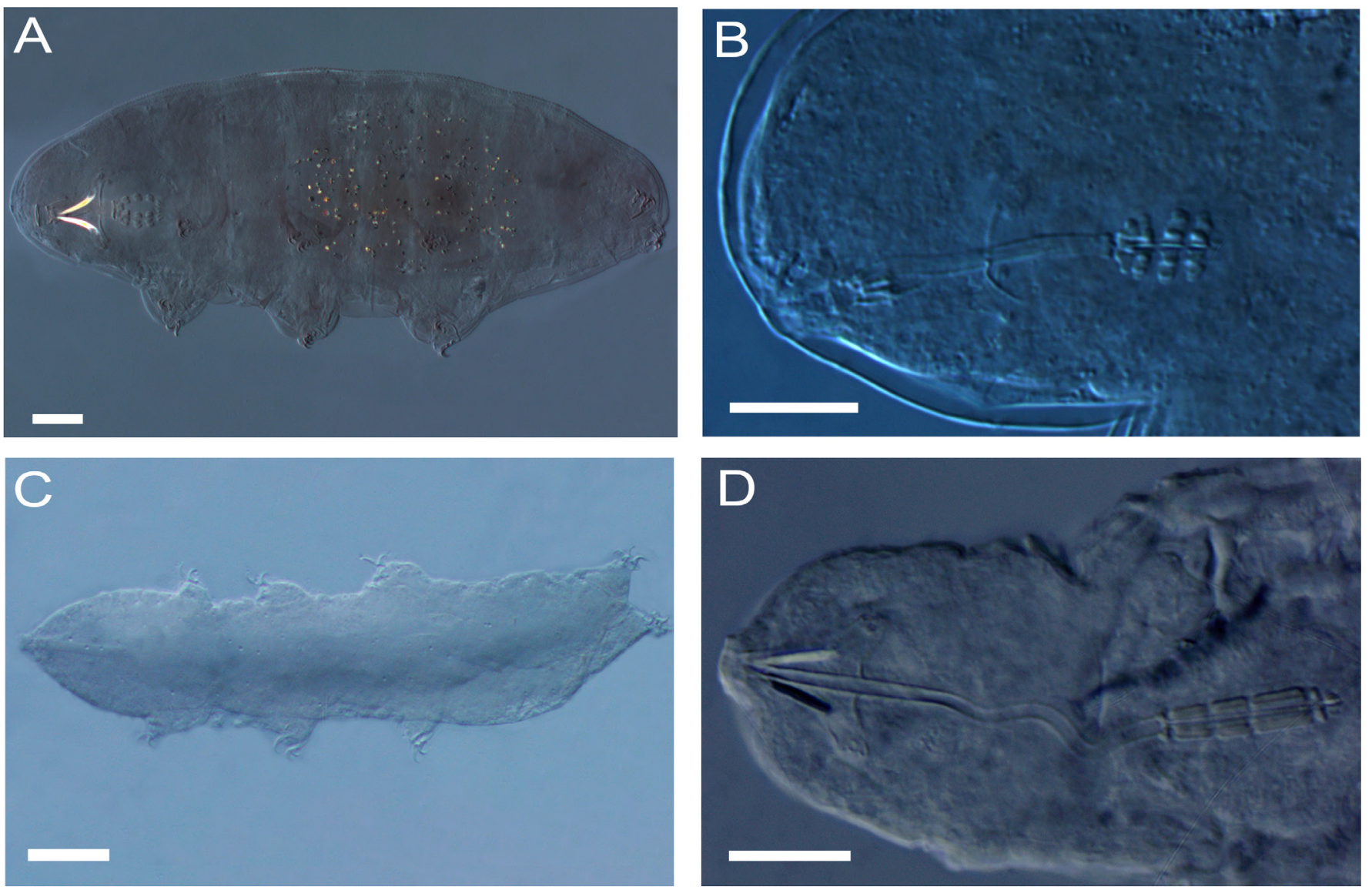

Figure 5. DIC photomicrograph of Tardigrada. A: Dorsal view of Macrobiotus sp 1. B: Buccal apparatus of Minibiotus sp. C: Ventral view of Itaquascon umbellinae. D: Buccal apparatus of Adropion sp. Scale bars: $50 \mu \mathrm{m}$.

Table 4. Measurements [in $\mu \mathrm{m}$ ] of selected morphological structures of Itaquascon umbellinae de Barros R, 1939a.

\begin{tabular}{lc}
\hline CHARACTER & $\boldsymbol{\mu m}$ \\
\hline Body length & 243 \\
Buccal tube external width & 3.9 \\
Buccal tube internal width & 3.3 \\
Claw 1 heights & \\
External & 9.0 \\
External primary branch & 6.7 \\
External secondary branch & 5.0 \\
Internal & 6.1 \\
Claw 2 heights & \\
External & 10.6 \\
External primary branch & 7.5 \\
External secondary branch & 5.4 \\
Internal & 5.9 \\
Claw 3 heights & \\
External & 9.9 \\
External primary branch & 7.2 \\
External secondary branch & 4.5 \\
Internal & 5.8 \\
Claw 4 heights & \\
External & 11.4 \\
External primary branch & 8.8 \\
External secondary branch & 6.3 \\
Internal & 6.4 \\
\hline
\end{tabular}

2013). Kisielewski (1991) reported two species of Chaetonotus in Brazil with long spines on the dorsal region, C. bisacer and C. succinctus. Representatives of these species have spines arranged in a "belt" shape, differing from $C$. sp.1, which presents three spines closely inserted in three subsequent groups of spines. Araújo et al. (2013) also reported an unidentified species of Chaetonotus with long spines on the dorsal region, but with five and not nine as described for the present one.

Due to the shape and distribution of the dorsal and ventral scales and a pair of spines over the furcal base, the morphotype Chaetonotus sp. 2 is similar to two species reported for Brazil by Kisielewski (1991), C. intermedius and C. breviacanthus. However, C. sp. 2 differs from both species by the presence of a double-edge scale and by the pair of long spines at the furcal base. In comparison to $C$. intermedius, it was not possible to visualize the two pairs of ventral terminal scales and the cuticular pharyngeal rod. Additionally, in comparison to $C$. breviacanthus, conspicuous protuberance at the anterior edges of the hypostomium and the posterior "U" edge of the scales were not observed in any specimens of $C$. sp.2.

Despite the fact that tardigrades have a rigid and armored integument and morphological investigations of living individuals are not required, from the 12 morphotypes of Tardigrada found in the present study, eight were not identified to species level. This occurred because in many species the study of adult morphology alone is not enough for species identification (Nelson et al. 2015, Schill 2018). Very often it is necessary to analyze the eggs because they have essential taxonomic significance 
and show species-specific ornamentation. In particular, within the taxon Macrobiotidae, limnic and terrestrial tardigrades belonging to the genera Minibiotus Schuster, 1980, Macrobiotus Schultze, 1834 and Paramacrobiotus Guidetti, Schill, Bertolani, Dandekar \& Wolf, 2009 (see Dastych 1998, Meyer \& Hinton 2009, Kaczmarek et al. 2017), can only be properly identified if the eggs are available.

The genus Minibiotus has 50 described species morphologically diverse (Degma et al. 2020). According to recent studies, the results obtained with the use of integrative approach using genetic and detailed morphological data, e.g. in the description of the species Minibiotus ioculator Stec, Kristensen and Michalczyk 2020a, can clarify the species relationships and contribute with information for status polyphyletic of the group (Stec et al. 2020a).

The only four species of Minibiotus genus reported in Brazil were: Minibiotus acontistus (de Barros R 1942), Minibiotus intermedius (Plate 1888), Minibiotus julietae (de Barros R 1942) and Minibiotus marcusi (de Barros R 1942) (de Barros R 1942b, du Bois-Reymond Marcus 1944, Kaczmarek et al. 2015). Two Minibiotus morphospecies were sampled in the present study and one of them was very similar to M. acontistus described by de Barros R (1942b). Among the genus Macrobiotus, one of the most specious groups within Tardigrada, we were only able to highlight that Macrobiotus sp. 1 shows a very distinct dorsal cuticle ornamentation.

Three morphospecies of the genus Paramacrobiotus were found: Paramacrobiotus sp. 1, Paramacrobiotus sp. 2 e Paramacrobiotus sp. 3 . Despite that species belonging to this genus have a very restricted biogeographic distribution range (Kaczmarek et al. 2017), for an accurate description of any Paramacrobiotus species it is important to use an integrative taxonomy approach (Stec et al. 2020b). Furthermore, recentely the subgeneric classification was revisited and nomenclature acts and diagnoses were changed (Marley et al. 2018).

The genus Adropion Pilato, 1987 is currently composed of 15 species (Degma et al. 2020), and considered a polyphyletic group, represented by three independent evolutionary lineages (Gasiorek \& Michalczyk 2020). The unique species reported in Brazil was Adropion scoticum Murray, 1905 (de Barros R 1943, du Bois-Reymond Marcus 1944, Kaczmarek et al. 2015). However, we only found a single specimen and a detailed observation of the morphological traits was not possible and A. scoticum is considered a complex of species and a reanalysis of the taxon is necessary with an integrative taxonomy approach (Kaczmarek et al. 2015, Duenãs-Cedillo et al. 2020). Thus, we decided to keep as Adropion sp.

The last morphotype, Echiniscus sp. is very similar to Echiniscus succineus Gąsiorek \& Vončina 2019, only reported for the type locality in Madagascar. However, the specimen found in Serra do Japi differs from E. succineus by the presence of a small denticle on spines $\mathrm{D}^{\mathrm{d}}$ (absent in E. succineus) and lacks epicuticular thickenings at the edges of the dorsal plates (present in E. succineus). Given these morphological differences and considerable geographic distance, they are probably different species.

It is known that Brazilian freshwater and limnoterrestrial meiofauna organisms are poorly studied and their biodiversity is still underestimated (Garraffoni et al. 2017a, Kaczmarek et al. 2015, de Barros RC 2020). This perspective will only change if the number of surveys increases in the coming years. As the number of taxonomists specialized in these groups is very low in Brazil, the opportunity to show these lesser-known taxa to undergraduate students can potentially inspire the next generation of meiofaunal researchers. Despite some problems in sorting and identification routines due to students' inexperience, this study achieved important goals of teaching and provided an immersive experience for the students interested in these tiny animals.

\section{Acknowledgements}

We are thankful to FAPESP (Fundação de Amparo à Pesquisa do Estado São Paulo - 2014/23856-0; 2018/10313-0; 2018/11166-0; 2018/25213-0) for financial support and ICMBio for the research permits (SISBIO $n^{\circ}$ 69660). This study was financed in part by the Coordenação de Aperfeiçoamento de Pessoal de Nível Superior - Brasil (CAPES) - Finance Code 001. We also acknowledge Yasmina Shah Esmaeili for the English revision of the manuscript and Wagner Luiz dos Santos, Thamara Rodrigues dos Reis and Aurélio Fajar Tonetto for macrophytes and bryophytes identifications.

\section{Author Contributions}

Emiliana Brotto Guidetti: Contribution to data collection, data analysis and interpretation, manuscript preparation, and critical revision.

Ariane Campos: Contribution in the concept and design of the study, data collection, data analysis and interpretation, manuscript preparation, and critical revision.

Alan Rodrigo Batistão: Contribution to data collection, data analysis and interpretation, manuscript preparation, and critical revision.

Amanda Tognoli da Silva: Contribution to data collection, data analysis and interpretation, and manuscript preparation.

Carla Gabriela Bilatto: Contribution to data collection, data analysis and interpretation, and manuscript preparation.

Kelly Fernanda Acosta: Contribution to data collection, data analysis and interpretation, manuscript preparation, and critical revision.

Thiago Quintão Araújo: Contribution in the concept and design of the study, data collection, data analysis and interpretation, manuscript preparation, and critical revision.

André Rinaldo Senna Garraffoni: Contribution in the concept and design of the study, data collection, data analysis and interpretation, manuscript preparation, critical revision, and funding acquisition.

\section{Conflicts of Interest}

The authors declare that they have no conflict of interest related to the publication of this manuscript.

\section{References}

APPELTANS, W., AHYONG, S.T ANDERSON, G., ANGEL, M.V. ARTOIS, T., et al. 2012. The magnitude of global marine species diversity. Curr. Biol. 22(23):2189-2202.

ARAÚJO, T.Q., COIMBRA, F.A. \& GARRAFFONI, A.R.S. 2013. New records of Gastrotricha from Minas Gerais, Brazil. Stud. Neotrop. Fauna E. 48(1):68-75

ASSUNÇÃO, C.M.L. 1999. Tardigrada. In Biodiversidade do Estado de São Paulo: Síntese do conhecimento ao final do século XX-Invertebrados de Água Doce (D. Ismael., W.C. Valenti \& T. Matsumura-Tundisi, eds). Fundação de Amparo à Pesquisa do Estado de São Paulo, São Paulo, v.4, p.61-64.

BALSAMO, M., d'HONDT, J.L., KISIELEWSKI, J. \& PIERBONI, L. 2008. Global diversity of gastrotrichs (Gastrotricha) in fresh waters. Hydrobiologia. 595:85-91. 
BALSAMO, M., GRILLI, P., GUIDI, L. \& D'HONDT, J.L. 2014. Gastrotricha: Biology, Ecology and Systematics. Families Dasydytidae, Dichaeturidae, Neogosseidae, Proichthydiidae. Backhuys Publishers, Leiden.

BALSAMO, M., D'HONDT, J.L, KISIELEWSKI, J., TODARO, M.A., TONGIORGI, P., GUIDI, L., GRILLI, P. \& DE JONG, Y. 2015. Fauna Europaea: Gastrotricha. Biodivers Data J. 3:5800.

BALSAMO, M., ARTOIS, T., SMITH, J.P., TODARO, M.A., GUIDI, L., LEANDER, B.S. \& VAN STEENKISTE, N.W. 2020. The curious and neglected soft-bodied meiofauna: Rouphozoa (Gastrotricha and Platyhelminthes). Hydrobiologia. 847(12):2613-2644.

BARTYLAK, T., KULPA, A., GROBYS, D., KEPEL, M., KEPEL, A., KMITA, H. \& KACZMAREK, Ł. 2019. Variability of Echiniscus tristis Gąsiorek \& Kristensen, 2018-is morphology sufficient for taxonomic differentiation of Echiniscidae? Zootaxa. 4701:1-24.

BOECKNER, M.J., SHARMA, J. \& PROCTOR, H.C. 2009. Revisiting the meiofauna paradox: dispersal and colonization of nematodes and other meiofaunal organisms in low- and high-energy environments. Hydrobiologia. 624(1):91-106.

CERCA, J., PURSCHKE, G. \& STRUCK, T.H. 2018. Marine connectivity dynamics: clarifying cosmopolitan distributions of marine interstitial invertebrates and the meiofauna paradox. Mar. Biol. 165(8):123.

CLAPS, M.C. \& ROSSI, G.C. 1988. Contribucion al conocimiento de los tardigrados de Argentina VI. Iheringia Ser. Zool. 38(1):45-50.

DASTYCH, H. 1998. Description of eggs in the Antarctic tardigrade Minibiotus stuckenbergi (Dastych et al. 1990) (Tardigrada, Macrobiotidae). Entomol. Mitt. zool. Mus. Hamb. 12:289-294.

DE BARROS, R. 1939a. Itaquascon umbellinae gen. nov. spec. nov. (Tardigrada, Macrobiotidae). Zool. Anz. 128:106-109.

DE BARROS, R. 1939b. Pseudechiniscus juanitae nova espécie de tardígrado. Boletim Biológico. 4:367-368.

DE BARROS, R. 1942a. Tardígrados do Estado de São Paulo, Brasil. I. Introdução. Gêneros "Echiniscus" e "Pseudechiniscus". Rev. Bras. Biol. 2:257-269.

DE BARROS, R. 1942b. Tardígrados do Estado de São Paulo, Brasil. II. Gênero "Macrobiotus". Rev. Bras. Biol. 2(4):373-386.

DE BARROS, R. 1943. Tardígrados do Estado de São Paulo, Brasil. III. Gêneros Hypsibius, Itaquascon e Milnesium. Rev. Bras. Biol. 3:1-10.

DE BARROS, R.C. 2020. Tardigrades Research in Brazil: an overview and updated checklist. Arq. Zool. 51(1):1-11.

DEGMA, P., BERTOLANI, R. \& GUIDETTI, R. 2020. Actual checklist of Tardigrada species. (Last access on 23/10/2020)

DU BOIS-REYMOND MARCUS, E. 1944. Sobre tardígrados brasileiros. Com. Zool. Mus. Montevideo. 1(13):1-19.

DUEÑAS-CEDILLO, A., MARTÍNEZ-MÉNDEZ, E., GARCÍA-ROMÁN, J., ARMENDÁRIZ-TOLEDANO, F. \& RUIZ, E.A. 2020. Tardigrades from Iztaccíhuatl Volcano (Trans-Mexican Volcanic Belt), with the description of Minibiotus citlalium sp. nov. (Eutardigrada: Macrobiotidae). Diversity. 12(7):271.

EHRENBERG, C.G. 1830. Organisation, Systematik, und geographisches Verhältnis der Infusionstierchen. F. Dümmler, Berlin.

FONSECA, G., FONTANETO, D. \& DI DOMENICO, M. 2018. Addressing biodiversity shortfalls in meiofauna. J. Exp. Mar. Biol. Ecol. 502:26-38.

FONTOURA, P., PILATO, G., \& LISI, O. 2008. Echiniscidae (Tardigrada, Heterotardigrada) from Faial and Pico Islands, the Azores, with the description of two new species. Zootaxa. 1693:49-61.

GARRAFFONI, A.R.S., ARAUJO, T.Q., LOURENCCO, A.P. \& BALSAMO, M. 2010. New data on freshwater psammic Gastrotricha from Brazil. ZooKeys. 60:1-12.

GARRAFFONI, A.R.S. \& MELCHIOR, M.P. 2015. New species and new records of freshwater Heterolepidoderma (Gastrotricha: Chaetonotidae) from Brazil with an identification key to the genus. Zootaxa. 4057(4):551.

GARRAFFONI, A.R.S. 2017. Checklist de Gastrotricha do estado do Mato Grosso do Sul, Brasil. Iheringia Ser. Zool. 107: e2017104
GARRAFFONI, A.R.S., ALCÂNTARA, F.C. \& CHECON, H.H. 2017 a. Evaluating the anesthetization and fixation efficacy of "soft" and "hard" freshwater benthic meiofauna: what is the best method for specimen preservation? Limnology. 18(2):209-218.

GARRAFFONI, A.R.S., ARAÚJO, TQ., LOURENÇO, A.P., GUIDI, L. \& BALSAMO, M. 2017b. A new genus and new species of freshwater Chaetonotidae (Gastrotricha: Chaetonotida) from Brazil with phylogenetic position inferred from nuclear and mitochondrial DNA sequences. Syst. Biodivers. 15(1):49-62.

GARRAFFONI, A.R.S., ARAÚJO, T.Q., LOURENÇO, A.P., GUIDI, L. \& BALSAMO, M. 2019a. Integrative taxonomy of a new Redudasys species (Gastrotricha: Macrodasyida) sheds light on the invasion of freshwater habitats by macrodasyids. Sci. Rep. 9(1):1-15.

GARRAFFONI, A.R.S., KIENEKE, A., KOLICKA, M., CORGOSINHO, P.H., PRADO, J., NIHEI, S.S. \& FREITAS, A.V. 2019b. ICZN Declaration 45: a remedy for the nomenclatural and typification dilemma regarding softbodied meiofaunal organisms? Mar. Biodivers. 49:2199-2207.

GĄSIOREK, P. \& VONČINA, K. 2019. New Echiniscidae (Heterotardigrada) from Amber Mountain (Northern Madagascar). Evol. Syst. 3:29-39.

GĄSIOREK, P. \& MICHALCZYK, Ł. 2020. Phylogeny of Itaquasconinae in the light of the evolution of the flexible pharyngeal tube in Tardigrada. Zool. Scr. 49(4):499-515.

GIERE, O. 2009. Meiobenthology. The Microscopic Motile Fauna of Aquatic Sediments. Heidelberg: Springer-Verlag, Berlin.

GOSSE, P.H. 1864. The natural history of the hairy-backed animalcules (Chaetonotidae). The Intellectual Observer. 5:387-406.

GUIDETTI, R., SCHILL, R.O., BERTOLANI, R., DANDEKAR, T. \& WOLF, M. 2009. New molecular data for tardigrade phylogeny, with erection of Paramacrobiotus gen. nov. J. Zoolog. Syst. Evol. Res. 47:315-321.

GUIL, N., JØRGENSEN, A. \& KRISTENSEN, R. 2019. An upgraded comprehensive multilocus phylogeny of the Tardigrada tree of life. Zool. Scr. 48:120-137.

HIGGINS, R.P. \& THIEL, H. 1988. Introduction to the Study of Meiofauna. Smithsonian Institution Scholarly Press, Washington, D.C

D’HONDT, J.L. 1971. Gastrotricha. Oceanogr. Mar. Biol. 9:141-192.

D'HONDT, J.L. 2006. Description de deux nouveaux genres et de trois nouvelles espèces de bryozoaires cténostomes. Bull. de la Soc. Zool. Fr. 131(4):247-260

IHAROS, G. 1963. The zoological results of Gy. Topal's collections in South Argentina, 3. Tardigrada. Annls hist.-nat. Mus. natn. hung. 55:293-299.

KACZMAREK, Ł., MICHALCZYK, Ł. \& MCINNES, S.J. 2015. Annotated zoogeography of non-marine Tardigrada. Part II: South America. Zootaxa. 3923:1-107.

KACZMAREK, Ł., GAWLAK, M., BARTELS, P.J., NELSON, D.R. \& ROSZKOWSKA, M. 2017. Revision of the genus Paramacrobiotus Guidetti et al., 2009 with the description of a new species, re-descriptions and a key. Annal Zool. 67(4): 627-656.

KACZMAREK, Ł. \& MICHALCZYK, Ł. 2017. The Macrobiotus hufeland group (Tardigrada) revisited. Zootaxa, 4363(1):101-123.

KIENEKE, A. \& SCHMIDT-RHAESA, A. 2015. Gastrotricha. In Handbook of Zoology (A., Schmidt-Rhaesa, ed.). Walter De Gruyter, Berlin, v. 3, p.1-126.

KISIELEWSKI, J. 1981. Gastrotricha from raised and transitional peat bogs in Poland. Monogr. Fauny Pol. 11

KISIELEWSKI, J. 1991. Inland-water Gastrotricha from Brazil. Annal. Zool. 43(2):1-166.

MARCUS, E. 1927. Zur Anatomie und Ökologie mariner Tardigraden. Zool. Jahrb. Abt. Syst. Geog. Biol. Tiere. 53:487-558

MARLEY, N.J., GAWLAK, M., BARTELS, P.J., NELSON, D.R., ROSZKOWSKA, M. \& DEGMA, P. 2018. A clarification for the subgenera of Paramacrobiotus Guidetti, Schill, Bertolani, Dandekar and Wolf, 2009, with respect to the International Code of Zoological Nomenclature. Zootaxa, 4407(1):130-134 
MAUCCI, W. 1974. Hypsibius (H.) cataphractus (Tardigrada: Macrobiotidae) und weitere Nachrichten über Tardigraden aus österreich. Ber. nat.-med. Ver. Innsbruck. 61:83-86.3.

MAUCCI, W. 1988. Tardigrada from Patagonia (Southern South America) with description of three new species. Rev. Chil. Entomol. 16:5-13.

MEYER, H.A. \& HINTON, J.G. 2009. The Tardigrada of southern Africa, with the description of Minibiotus harrylewisi, a new species from KwaZulu-Natal, South Africa (Eutardigrada: Macrobiotidae). Afr. Invertebr. 50(2):255-268

MICHALCZYK, Ł. \& KACZMAREK, Ł. 2013. The Tardigrada Register: a comprehensive online data repository for tardigrade taxonomy. J. Limnol. 72(1):175-181

MIHELCIC, F. 1962. Tardigrada. In Catalogus faunae Austriae: systematisches Verzeichnis aller österreichischem Gebiet festgestellten Tierarten (SPRINGER, ed.) Wien, p. 6:1-11.

MOREK, W., STEC, D., GASIOREK, P., SCHILL, R.O., KACZMAREK, Ł. \& MICHALCZYK, Ł. 2016. An experimental test of eutardigrade preparation methods for light microscopy. Zool. J. Linn. Soc. 178(4):785-793.

MOREK, W., CIOSEK, J.A. \& MICHALCZYK, Ł. 2020. Description of Milnesium pentapapillatum sp. nov., with an amendment of the diagnosis of the order Apochela and abolition of the class Apotardigrada (Tardigrada). Zool. Anz. 288:107-117.

MORELLATO, L.P.C. 1992. História natural da Serra do Japi: ecologia e preservação de uma área florestal no sudeste do Brasil. UNICAMP, Campinas.

MURRAY, J. 1905. The Tardigrada of the Scottish Lochs. Trans. R. Soc. Edinburgh. 41:677-698.

NELSON, D.R., GUIDETTI, R. \& REBECCHI, L. 2015. Phylum Tardigrada. In Ecology and General Biology: Thorp and Covich's Freshwater Invertebrates (J.H. Thorp \& D.C. Rogers, eds). Elsevier, Amsterdam, v.1, p.347-380.

PILATO, G. 1969. Evoluzione e nuova sistemazione degli Eutardigrada. Ital. J. Zool. 36(3):327-345.

PILATO, G. 1981. Analisi di nuovi caratteri nello studio degli Eutardigradi. Animalia, 8:51-57.

PILATO, G. 1987. Revision of the genus Diphascon Plate, 1889, with remarks on the subfamily Itaquasconinae (Eutardigrada, Hypsibiidae). In Biology of Tardigrades (R. Bertolani, R. (Ed.). Selected Symposia and Monographs, U.Z.I., Modena, v. 1, p. 337-357.

PILATO, G., BINDA, M.G. \& CLAXTON, S. 2002a. Itaquascon unguiculum and Itaquascon cambewarrense two new species of eutardigrades from Australia. N.Z.J.Zool. 29(2):87-93.

PILATO, G., BINDA, M.G., NAPOLITANO, A. \& MONCADA, E. 2002b. Remarks on some species of tardigrades from South America with the description of two new species. J. Nat. Hist. 38(9):1081-1086.

PINTO, H.S., ORTOLANI, A.A. \& ALFONSI, R.R. 1972. Estimativa das temperaturas médias mensais do Estado de São Paulo em função de altitude e latitude. Cadernos de Ciências da Terra, Universidade de São Paulo, Instituto de Geografia. São Paulo.

PLATE, L. 1888. Beiträge zur Naturgeschichte der Tardigraden. Zool. Jahrb. Abt. Syst. Geog. Biol. Tiere. 3:487-550.

RAMAZZOTTI, G. \& MAUCCI, W. 1983. II Phylum Tardigrada. Terza edizione riveduta e corretta. Memorie dell'Isituto Italiano di Idrobiologia Dott. Marco De Marchi. 41:1-1012.

RAO, G.C. \& CLAUSEN, C. 1970. Planodasys marginalis gen. et. sp. nov. and Planodasyidae fam. nov. (Gastrotricha Macrodasyoidea). Sarsia. 42:73-82.

REMANE, A. 1927. Beitrage zur Systematik der Susswassergastrotrichen. Zool. Jahrb. Abt. Syst. Geog. Biol. Tiere. 53:268-320.
RICHTERS, F. 1926. Tardigrada. In Handbuch der Zoologie (W. Kükenthal, T. Krumbach, W. Gruyter \& Co, eds). Berlin and Leipzig, v.3, p.58-61.

ROCHA, C.M.C., GOMES JÚNIOR, E.L. \& SANTOS, E.C.L. 2016. Brazilian limnoterrestrial tardigrades (Bilateria, Tardigrada): new occurrences and species checklist updates. Rev. Nord. Zoo. 10: 21-31.

ROSZKOWSKA, M., GROBYS, D., BARTYLAK, T., GAWLAK, M., KMITA, H., KEPEL, A. \& KACZMAREK, Ł. 2020. Integrative description of five Pseudechiniscus species (Heterotardigrada: Echiniscidae: the suillusfacettalis complex). Zootaxa 4763(4):51-484

RUDESCU, L. 1964. Tardigrada, Fauna Republicii Socialiste Populare Romania, Arthropoda, 4(7):1.400.

SCHILL, R.O. 2018. Water Bears: The Biology of Tardigrades. Springer International Publishing.

SCHULTZE, C.A.S. 1834. Macrobiotus hufelandii animal e crustaceorum classe novum, reviviscendi post diuturnam asphixiam et aridiatem potens, etc. 8 , 1 tab. C. Curths, Berlin.

SCHULTZE, C.A.S. 1840. Echiniscus bellermanni, Animal Crustaceum, Macrobiotus hufelandii affine. Berlin, apud G. Reimer, 1-8.

SCHUSTER, R.O. \& GRIGARICK, A.A. 1966. Tardigrada from the Galápagos and Cocos Islands. Proc. Calif. Acad. Sci. 34:315-328.

SCHUSTER, R.O., NELSON, D.R., GRIGARICK, A.A. \& CHRISTENBERRY, D. 1980. Systematic criteria of the Eutardigrada. Trans. Am. Micros. Soc. 99(3):284-303.

SCHWANK, P. 1990. Gastrotricha. In Süsswasserfauna von Mitteleuropa, Band 3. Gastrotricha und Nemertini (J. Schwoerbel \& P. Zwick, eds.). Gustav Fischer Verlag, Stuttgart, Jena, New York, p.1-252.

STEC, D., KRISTENSEN, R.M. \& MICHALCZYK, Ł. 2020a. An integrative description of Minibiotus ioculator sp. nov. from the Republic of South Africa with notes on Minibiotus pentannulatus Londoño et al., 2017 (Tardigrada: Macrobiotidae). Zool. Anz. 286:117-134.

STEC, D., KRZYWAŃSKI, Ł., ZAWIERUCHA, K. \& MICHALCZYK, Ł. 2020b. Untangling systematics of the Paramacrobiotus areolatus species complex by an integrative redescription of the nominal species for the group, with multilocus phylogeny and species delineation in the genus Paramacrobiotus. Zool. J. Linn. Soc. 188(3):694-716.

THULIN, G. 1911. Beiträge zur Kenntnis der Tardigradenfauna Schwedens. Ark. Zool. 7:1-60.

THULIN, G. 1928. Über die Phylogenie und das System der Tardigraden. Hereditas. 11(2-3):207-266.

UTSUGI, K. 1988. Tardigrades in Hokkaido area. Zool. Sci. 5(6): 1335.

VALKANOV, A. 1937. Über die Gastrotrichen Bulgariens. Zool. Jahrb. Abt. Syst. Geog. Biol. Tiere. 70:171-176.

VICENTE, F. 2010. Micro-invertebrates conservation: forgotten biodiversity. Biodivers. Conserv. 19(13):3629-3634.

VON DADAY, E. 1905. Untersuchungen über die Süsswasser-Mikrofauna Paraguays. Zoologica, Stuttgart.

WANG, L. 2009. Tardigrades from the Yunnan-Guizhou Plateau (China) with description of two new species in the genera Mixibius (Eutardigrada: Hypsibiidae) and Pseudechiniscus (Heterotardigrada: Echiniscidae). J. Nat. Hist. 43(41-42):2553-2570.

ZELINKA, C. 1889. Die Gastrotrichen. Eine monographische Darstellung ihrer Anatomie, Biologie und Systematik. Z. Wiss. Zool. 49:209-384.

Received: 24/11/2020

Revised: 06/02/2021

Accepted: 09/03/2021

Published online: 03/05/2021 